\title{
AGRICULTURAL EXPORTS AND PERFORMANCE OF AGRICULTURAL FIRMS IN INDIA: AN EMPIRICAL ANALYSIS USING SYSTEM GMM
}

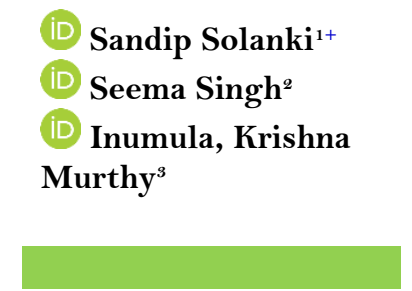

\section{Article History \\ Received: 6 December 2021 Revised: 10 January 2022 Accepted: 26 January 2022 Published: 28 February 2022 \\ Keywords \\ Agricultural raw materials exports \\ GMM model \\ Financial performance \\ Agriculture value added \\ Indian agriculture firms \\ Correlation and sectoral performance.}

\section{JEL Classification:} C51, E44, Q17.

\author{
${ }^{1, s}$ Symbiosis Institute of International Business, Symbiosis International \\ (Deemed University), Pune, Maharashtra, India. \\ 'Email: sandip.solanki@siib.ac.in Tel: 7600009029 \\ ${ }^{s}$ Email:dr.krishna@siib.ac.in Tel: 7743875584 \\ ${ }^{2}$ Symbiosis Centre for Corporate Education, Symbiosis International (Deemed \\ University), Pune, Maharashtra, India.

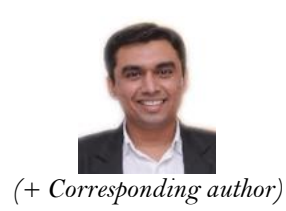

¿Email: director@scce.edu.in Tel: 9823067278

ABSTRACT

The relationship between agricultural exports and agricultural company performance in India is investigated in this research. The objective of the study is to find the relationship among agriculture firms' financial performance and agriculture exports and macroeconomic indicators. System generalized method of moments (GMM) models are used to explore the dynamic linkage between exports and firm performance from 2012 to 2019. The findings indicate that agriculture exports have a significant negative correlation with interest rates, and the value addition of exports to GDP indicates that higher interest rates and more value addition to GDP results in a reduction in agriculture exports. This negative relationship between agriculture exports and the profitability of firms implies that an increase in exports potentially reduces the profit margins. The agriculture firms' financial performance is closely monitored with agriculture exports, which facilitates the exploration of sectoral performance and can be linked with export performance for future studies. The study results cannot be generalized to the other countries due to demographic and other natural constraints. The results are critical for decision makers who want to develop strategies that support the agriculture sector. Implementing the right policies may incentivize investment in this industry. Furthermore, the results have significant theoretical consequences, bridging the theoretical and experimental literature gaps in the agricultural sector.

Contribution/Originality: In an Indian context, this study provides a unique contribution by directly measuring the financial performance of agriculture firms using agriculture exports and the value of their contribution to economic growth. The application of the dynamic panel regression (GMM) model provides an accurate measurement to study the performance of agriculture firms based on agriculture exports and other macroeconomic variables.

\section{INTRODUCTION}

India's agricultural sector has been the country's economic backbone for many years. Agriculture, with its allied sectors, is unquestionably the largest livelihood provider in India. By generating agricultural products for internal consumption and earning foreign cash through exports, the agricultural industry contributes to the country's economic growth. Approximately $54.6 \%$ of the total workforce in the country is involved in the agricultural and allied sectors (Economic Survey, 2021), which is almost 50\% of the Indian workforce, and contributes $17.8 \%$ to the country's GDP (Economic Survey, 2021). While the non-agricultural sectors suffered as a result of COVID-induced lockdowns, the agriculture sector grew at a solid pace of 3.4\% at constant prices during 2020-21 (Economic Survey, 2021). With 
India's broad-based economic expansion, agriculture's contribution to GDP is rapidly shrinking. Agriculture, however, is India's most populous economic sector and plays a key role in the country's entire socioeconomic fabric. The economic growth of a country is determined by the growth of its exports, and as an agrarian country, India's agriculture exports have played a major role in shaping the economy and occasionally achieving a trade surplus in agriculture commodities over the years.

The government of India, under the Atmanirbhar Bhartat Abhiyan, has taken several steps to strengthen and support the agricultural sector. Indian agricultural firms export raw materials as well as finished products. International trade impacts the financial performance of agricultural export firms as well as the economy as a whole. India's agricultural and allied exports amounted to approximately Rs. 252 thousand crores during 2019-20 (Economic Survey, 2021). India's agricultural export basket accounts for over $2.5 \%$ of world's agricultural trade (Economic Survey, 2021).

This study is organized in to five sections. Section 1 contains the introduction to the topic followed by the relevant literature review in Section 2. The third section presents the data and methodology employed for the empirical analysis. In the fourth section, the outcomes found from the econometric analyses are presented, and the final section provides the conclusions.

\section{LITERATURE REVIEW}

Several researchers have explored the relations between agriculture and economic growth (Donovan, 1996; Izuchukwu, 2011; Katircioglu, 2006; Tiffin \& Irz, 2006), and various scholars have presented hypotheses in support of agriculture-led growth (Awan \& Aslam, 2015; Awokuse \& Xie, 2015; Hwa, 1988). There is also a large number of studies supporting the agricultural-led growth hypothesis regarding specific countries, such as Nigeria (Olajide, Akinlabi, \& Tijani, 2012; Yusuf, 2014) and Thailand (Jatuporn, Chien, Sukprasert, \& Thaipakdee, 2011). It has been well documented that agricultural growth is very important for economic growth for countries which have very limited access to international markets (Gollin, 2010). Similarly, Raza, Ali, \& Mehboob (2012) explored the role that the agriculture sub-sector plays in the economic growth of Pakistan. It was also noted that the agriculture sector is the driving force of the Chinese economy (Yao, 2000). Memon, Baig, \& Ali (2008), using time series data from 1971 to 2007 , confirmed that agricultural GDP plays a significant role in the export enhancement of Pakistan.

Studies have been presented that investigate factors that influence agricultural exports (Abolagba, Onyekwere, Agbonkpolor, \& Umar, 2010; Boansi, 2013). Various studies also explore the impact of agriculture exports on economic growth in various economies, such as South Africa (Bulagi, Hlongwane, \& Belete, 2015), Tunisia (Bakari, 2017a, 2017b), Southeastern European countries (Bakari \& Mabrouki, 2017), Nigeria (Ijirshar, 2015; Verter \& Bečvářová, 2016), and India (Ohlan, 2013). Moreover, similar results were also noted by Sanjuán-López \& Dawson (2010) for 42 developing countries. These studies have the common finding that agriculture exports help to drive economic growth.

In addition to these, several other studies have explored the influence of agricultural raw material exports on the economic growth of a country and, in the case of Pakistan, found that exporting agricultural raw materials has a positive impact on GDP. Khan, Salam, \& Batool (2015) and Sheefeni \& Simon (2016) also achieved similar results for Namibia for the period from 1998 to 2014, revealing that primary commodities exports drives Namibia's economic development but Namibia's economic development does not positively contribute to the export of primary commodities. Ojo, Awe, \& Ogunjobi (2014) revealed that the economic growth of Nigeria is determined by various macroeconomic factors, such as agriculture exports, agriculture output, net capital flow and the world price of Nigeria's major agricultural commodities. Ahmed \& Sallam (2018) confirmed a favorable correlation between the export of agricultural products and agriculture's share of GDP in Egypt. It was also noted that rice exports help to stimulate economic growth in rice exporting economies (Kang, 2015). However, other studies presented weak links between agricultural export growth and economic growth. Mehrara \& Baghbanpour (2016) presented that the link 
between agriculture exports and economic growth was weak in 34 developing countries between 1970 and 2004 . Mahmood \& Munir (2018) confirmed that agricultural exports had a favorable but insignificant relation to Pakistan's GDP growth from 1970 to 2014.

Urriola, Aquino Rodriguez, \& Baral (2018) highlighted that traditional agricultural exports had a favorable but non-significant effect, but non-traditional agricultural exports had a favorable and substantial outcome on Peru's economic growth from 2000 to 2016. Simasiku \& Sheefeni (2017) showed that the gross domestic product (GDP) of Namibia between 1990 and 2004 was affected favorably and significantly by the export of agricultural products, but this was not the case with reference to non-agricultural exports. In some studies, it was observed that the export of some agricultural products, such as coffee and bananas, have a favorable and significant effect on economic growth (Gilbert, Linyong, \& Divine, 2013). In one study, Faridi (2012) observed that the economic growth of Pakistan between 1972 and 2008 was affected unfavorably and significantly by the export of agricultural products. Edeme, Ifelunini, \& Nkalu (2016) found that agricultural exports have not played a significant role in the economic growth of 15 ECOWAS countries from 1980 to 2013. Khan \& Lodhi (2014) showed that financial development, agriculture raw material exports, and output growth all have a long-term relationship in Pakistan from 1980 to 2012. Shah, Haq, \& Farooq (2015) depicted that Pakistan's agricultural exports have an adverse association with economic growth, while non-agriculture exports have a favorable connection with economic growth. Scholars have also investigated the role of growth in production and economic growth in export growth. Abbas (2012) used the Johansen test of cointegration and Granger causality, and concluded that in both the short and long runs only production growth increased exports between 1975 and 2010 for Pakistan. Ronit \& Divya (2014) confirmed the theory that economic growth promoted higher exports from India between 1969 and 2012. There has been a general lack of consensus among economists about the basic relationship between exports and economic development. The theory proposed here is that the two have a causal relationship. Baharumshah \& Rashid (1999) suggested that Malaysia's economic development can be supported by an export expansion policy. Ekanayake (1999) showed that export growth and economic growth have a bidirectional causal relationship in various economies. In Malaysia, there is also evidence that exports help to achieve economic growth. Emery (1967) showed that the strongest link was found between exports and gross national product (GNP) for a group of 50 countries. Fosu (1990) found that export growth favorably affected the economic growth of 28 less developed countries (LDCs). Similar results were also found in the case of Japan. Export expansion is a significant variable for Japanese economic growth, and there is a causal relationship between export growth and economic growth (Hatemi-j, 2002).

Njimanted \& Aquilas (2015) observed that, in the short run, the export of timber had a negligible impact on economic development in Cameroon, while it had a major positive impact in the long run. Tang, Lai, \& Ozturk (2011) observed that exports and GDP of Asia's four economies are cointegrated, implying that there is a long-run relationship between the variables. Ali (2017) found that exchange rate fluctuation favorably impacted both intensive and extensive margins (IM and EM) in the case of Pakistan between 2000 and 2013. Buguk, Isik, Dellal, \& Allen (2003), using an error correction model, highlighted that the exchange rate and its volatility had little effect on Turkish exports. Chi \& Cheng (2016) suggested that volatility in the exchange rate continues to be a very important factor that influences the number of maritime exports from Australia, and the results also highlighted that the real income of Asian trading partners is also a crucial element of Australia's maritime exports. Huchet \& Korinek (2011) found that fluctuations in exchange rate only slightly impact trade flows in China. Mousavi \& Leelavathi (2013) conducted a study using the Granger causality analysis for the period between 1980 and 2010 and found no link between the volume of agricultural exports and the real exchange rate, i.e., neither variable causes the other in either direction. The findings also indicated that these factors are not co-related, indicating that there is no connection between agricultural exports and exchange rates in the long run for India. Ojede (2015) used a vector autoregressive model to show that volatility in exchange rates had a greater impact on service exports than on agricultural exports in the United States between 1992 to 2009. Tulasombat \& Ratanakomut (2015) presented that exchange rates had 
substantial adverse impacts on Thailand's rice and rubber exports. Wong \& Lee (2016) identified that fluctuating exchange rates have a major effect on real exports of Malaysian manufactured goods to China. Furthermore, exchange rate fluctuations may have a favorable or unfavorable impact on real export. The calculation is done using the Johansen cointegration process and the dynamic ordinary least squares (DOLS) estimator. Reaz et al. (2017) showed that the volatility of the exchange rate harmed the financial output of Malaysian agriculture firms from 2001 to 2015. Ayinde, Ayanwale, Shittu, \& Kareem (2013) conducted a study on the performance of major agricultural-based companies listed on the Nigerian stock exchange (NSE) by using a time series analysis over 11 years, from 1998 to 2008. The results of this study revealed that the volume of shares traded is favorably correlated to dividend yield and current market price, while it is unfavorably correlated to earning yield, earnings per share and dividend. The priceearnings ratio (PER) rises along with rising earnings per share and dividend but decreases with a rise in earnings yield and current market price. In another study, Gill, Mand, Obradovich, \& Mathur (2018) presented that newer agribusiness firms with financial support from non-resident family members perform better than those without the same financial support. Issah \& Antwi (2017) highlighted that firm performance is determined by the previous year's ROA and macroeconomic factors. Kiganda (2014) conducted a study to determine if bank profitability and macroeconomic variables in Kenya have a connection over a period of five years from 2008 to 2012 using the OLS method. The paper confirmed that macroeconomic variables, such as real GDP, inflation and exchange rate, do not affect bank profitability significantly, while internal variables associated with bank management are the significant determinants of bank profitability in Kenya.

Murigu (2014) conducted a study in Kenya spanning for four financial years from 2009 to 2012 and found that leverage, equity capital and the management competence index are significant factors of profitability in general insurance firms, while both firm size and the ownership structure of general insurance companies have a significant but adverse effect on their profitability. In another study, Mwangi (2013) found that asset returns of airline companies had a weak, favorable, non-significant association with the rate of economic development and annual change in the M3 money supply of 109 airline companies within Kenya for five years from 2008 to 2012. The paper also presented that ROA had a poor, unfavorable, irrelevant association with the exchange rate, annual average lending rate, and annual average inflation rate. Furthermore, macroeconomic factors affected the ROA, according to the report. Ongeri (2014) using regression and correlation analyses on the financial performance of 112 non-banking financial institutions in Kenya for a period of 10 years from 2004 to 2013. The results revealed that the asset returns of nonbanking financial institutions have a robust affirmative association with the exchange growth rate (2.504) and a weak favorable connection with quarterly GDP (0.284), rate of inflation (0.655), and quarterly rate of interest (1.107). Reaz, Bowyer, Vitale, Mahi, \& Dahir (2020) observed that the performance of agricultural firms in Malaysia between 2002 and 2016 was positively associated with the export of agricultural products, but the results did not display any positive effect of agricultural raw materials on the performance of agricultural firms. Singh, Misra, Kumar, \& Tiwari (2019) used a panel regression analysis to examine the determinants of financial performance of 37 US agricultural organizations. The paper presented that the US agricultural cooperatives are extremely sensitive to the uncertainty of macroeconomic policy, and there is an opposite relationship between the size of US agricultural cooperatives and the profitability of these firms from 2009 to 2017 . Kohler \& Ferjani (2018) revealed that agricultural and food product exports declined in the long run because of the appreciation in the exchange rate of the Swiss economy from 1999 to 2012. This study was conducted using time series and dynamic panel data. Mao (2019) found similar results for the Chinese economy where exchange rate appreciation reduces agricultural exports.

\section{DATA \& METHODOLOGY}

3.1. Data

The study uses panel data on agriculture firms' financial indicators, namely net profit margin and return on assets, along with the explanatory variables of agricultural raw materials exports: agriculture value added, interest 
rate, inflation growth, and gross domestic product over eight years from 2012 to 2019. The data variables were extracted from the Centre for Monitoring Indian Economy (CMIE) and the World Bank's Development Indicator database. In this study, the financial performance of agriculture firms is taken as the dependent variable and is proxied by net profit margin (NPM) and return on assets (ROA); agricultural raw materials exports (AEXP) and agriculture value added (AVAL) are taken as independent variables; and interest rate (INTE), inflation growth (INFL) and GDP growth act as control variables.

The functional relationship among the data variables are defined as:

Firm Performance $=\mathrm{f}\{$ AEXP, AVAL, INTE, INFL, GDP $\}$

The GMM (difference) model, which is also known as the dynamic panel model, can be written as:

$$
\begin{aligned}
N P M_{i t} & =N P M_{i t-1}+\alpha_{1 i} A E X P_{i t}+\alpha_{2 i} A V A L_{i t}+\alpha_{3 i} I N T E_{i t}+\alpha_{4 i} I N F L_{i t}+\alpha_{5 i} G D P_{i t}+\varepsilon_{i t} \\
R O A_{i t} & =R O A_{i t-1}+\beta_{1 i} A E X P_{i t}+\beta_{2 i} A V A L_{i t}+\beta_{3 i} I N T E_{i t}+\beta_{4 i} I N F L_{i t}+\beta_{5 i} G D P_{i t}+\varepsilon_{2 t}
\end{aligned}
$$

Where the current year's financial performance depends on the previous year and the other explanatory variables.

\subsection{Generalized Method of Moments (GMM)}

When the lagged dependent variable is included as one of the regressors in the model, the conventional panel fixed and dynamic models will become less efficient and will generate biased estimates due to the relation between the model error term and the lagged dependent variable. The alternative is to take the first differences of the original model, originally suggested by Anderson \& Hsiao (1981), also known as the difference GMM model or dynamic panel regression model. The removal of a constant term and individual effect means that the first difference equation is modelled as a function of instrumental variables.

Arellano \& Bond (1991) proposed two specification tests. If the errors in levels were uncorrelated, we would expect T1 (test for AR (1) errors) to be significant, but not T2 (test for AR (2) errors). The absence of correlation between errors and instruments is very important to establish the consistency of the estimates (Sargan test), and the Wald test is used to test the joint significance of all variables in the model.

\section{RESULTS AND DISCUSSIONS}

Table 1 provides the summary statistics for the dependent and explanatory variables used in the model to assess the impact of firm level variables on the financial performance of the Indian agriculture firms. The means, medians and standard deviations were reported along with the minimum and maximum values. A total of 400 observations were used in the study across 50 cross-sectional units. The dependent variables NPM and ROA both show negative mean values, indicating that the financial performance of Indian agriculture firms is very poor implying more outflows than inflows. On average, the net profit margin was negative $151 \%$, and the return on assets has a negative value of $2.59 \%$. The contribution from agriculture, as indicated by its exports and value addition to GDP, has positive average values, and the agriculture exports showed an average growth of $1.75 \%$ and a value addition of $17.7 \%$. During the study period, the interest rate had an average of $5.55 \%$, inflation stood at $6.41 \%$ and growth in the GDP value was about $7 \%$. The profitability showed a lot of variations in the study period, followed by macroeconomic variables, whereas the agriculture contribution showed fewer variations during the study period. The maximum positive ROA achieved in the study period was about $44 \%$, with the highest GDP growth at $10.3 \%$ and a low inflation rate of $2.49 \%$. The highest lending rate was about $12 \%$. The agriculture contribution in terms of exports rose from a minimum of $1 \%$ to a maximum of $4 \%$, and agriculture's value addition showed a minimum of $15 \%$ and a maximum of $22 \%$ during the study period.

The strength and direction of the relationship between the variables are important to determine whether the variables have a positive or negative relationship between them. The correlation coefficient value generally lies between -1 and +1 . Values close to +1 indicate a positive correlation, and values close to -1 indicate a negative 
correlation. Table 2 gives an understanding of how the data variables are related to each other, a smaller correlation value between the explanatory variables indicates that there is no multicollinearity problem in the model estimation.

Table 1. Summary statistics.

\begin{tabular}{c|c|c|c|c|c}
\hline Variable & Mean & Median & S.D. & Min. & Max. \\
\hline NPM & -151.000 & -17.000 & 532.000 & -6760.000 & 21.100 \\
\hline ROA & -2.590 & -1.050 & 9.180 & -89.300 & 43.800 \\
\hline AEXP & 1.750 & 1.550 & 0.723 & 1.060 & 4.100 \\
\hline AVAL & 17.700 & 17.300 & 1.740 & 15.400 & 21.900 \\
\hline INTE & 5.550 & 6.000 & 2.100 & 1.090 & 8.590 \\
\hline INFL & 6.410 & 5.540 & 2.730 & 2.490 & 12.000 \\
\hline GDP & 6.940 & 7.230 & 2.030 & 3.800 & 10.300 \\
\hline
\end{tabular}

Table 2. Correlation matrix.

\begin{tabular}{c|c|c|c|c|c|c|c}
\hline Variable & NPM & ROA & AEXP & AVAL & INTE & INFL & GDP \\
\hline NPM & 1.000 & & & & & & \\
\hline ROA & -0.120 & 1.000 & & & & & \\
\hline AEXP & $-0.28^{*}$ & $-0.07^{*}$ & 1.000 & & & & \\
\hline AVAL & $0.36^{*}$ & $0.16^{*}$ & $-0.36^{*}$ & 1.000 & & & \\
\hline INTE & $0.47^{*}$ & $0.23^{*}$ & $-0.65^{*}$ & $0.48^{*}$ & 1.000 & & \\
\hline INFL & 0.020 & -0.140 & $0.59^{*}$ & -0.330 & $-0.68^{*}$ & 1.000 & \\
\hline GDP & -0.020 & 0.170 & 0.060 & 0.430 & -0.230 & $0.13^{*}$ & 1.000 \\
\hline Note: ${ }^{*} 5 \%$ significance level.
\end{tabular}

The negative relationship between agriculture exports and the profitability of the firms implies that an increase in exports potentially reduces profit margins. Agriculture's value added and interest rate have a significant positive correlation with the profitability of the firms, indicating that higher interest rates and value added agriculture production increase the firms' revenues. Agriculture exports have a significant negative correlation with interest rates, and its value addition to GDP indicates that higher interest rates and more agriculture value addition to GDP results in a reduction in agriculture exports. However, a positive and significant relationship was found between inflation and agriculture exports. During the study period, there is a significant negative correlation between interest rate and inflation, and a significant positive correlation between GDP and inflation can be seen. The correlation matrix shows that all the correlation values are within the limits, which indicates that there is no collinearity between the explanatory variables; therefore, the problem of multicollinearity does not exist in the model estimation.

Table 3. Financial performance of India's agriculture industry.

\begin{tabular}{|c|c|c|c|c|}
\hline $\begin{array}{l}\text { Dependent } \\
\text { Explaniable } \\
\text { Variable }\end{array}$ & NPM & NPM Corrected & ROA & ROA Corrected \\
\hline Lagged NPM & $-0.27 * * *(0.00)$ & $-0.26^{* * *}(0.00)$ & - & - \\
\hline Lagged ROA & - & - & $0.18 * * *(0.00)$ & $0.17 * * *(0.00)$ \\
\hline AEXP & $-53.12(0.10)$ & $-31.44 * * *(0.00)$ & $-0.34(0.53)$ & $-1.15^{* * *}(\mathrm{O} .00)$ \\
\hline AVAL & $20.97(0.22)$ & $13.61^{* * * *}(\mathrm{O} .00)$ & $0.12(0.83)$ & $0.14(0.43)$ \\
\hline INTE & $35.38^{* * * *}(0.00)$ & $30.99^{* * * *}(\mathrm{O} .00)$ & $-0.37 *(0.08)$ & $-0.53^{* * *}(0.00)$ \\
\hline INFL & $29.16^{* * *}(0.00)$ & $21.77^{* * *}(0.00)$ & $-0.26^{*}(0.07)$ & $-0.10^{* * *}(0.04)$ \\
\hline GDP & $-0.23(0.86)$ & $0.51(0.79)$ & $0.77(0.00)$ & $0.46^{* * *}(0.00)$ \\
\hline No. of Observations & 350 & 350 & 350 & 350 \\
\hline No. of Instruments & 33 & 33 & 33 & 33 \\
\hline T1: AR (1) p-value & 0.00 & 0.01 & 0.00 & 0.00 \\
\hline T2: AR (2) p-value & 0.71 & 0.47 & 0.52 & 0.65 \\
\hline Sargan/Hausman & $20.77(0.75)$ & $25.07(0.51)$ & $20.8(0.77)$ & $19.10(0.84)$ \\
\hline Wald & $20.42^{* * *}(0.00)$ & $313.9^{* * * *}(\mathrm{O} .00)$ & $10.65^{*}(0.09)$ & $1021.69^{* * * *}(0.00)$ \\
\hline
\end{tabular}


After due consideration of econometric issues in the estimation of several models, the final results are presented in Table 3. First, the model is tested using the system GMM and difference GMM models based on the rule of thumb stated in the studies by Blundell \& Bond (1998) and Bond (2002). Based on the results of the pooled OLS and fixed effect models, it is concluded that the use of instruments is valid, and dynamic panel regression (difference GMM) is selected as the final model. The dynamic panel regression (difference GMM) model is used to test the financial performance of India's agriculture industry using the firm-specific variables AEXP and AVAL and the macroeconomic variables INTE, INFL and GDP. Table 3 gives the details of the model's significant estimates along with p-values enclosed in brackets. The second and fourth columns of Table 3 give the model estimates corrected for serial correlation and validity of instruments.

The coefficient of the lagged net profit margin (NPM) is negative and significant, which indicates a high persistence in margins, and although it's negative, the future performance depends on its previous performance. The coefficient of agriculture exports (AEXP) is negative and significant at a 1\% level, which is against the theory wherein a one-unit change in agriculture exports will result in a 31.44 decrease in net profit margin. The coefficient of AVAL is positive and significant, which indicates statistically that a one-unit change in agriculture value added will result in a $13.61 \%$ increase in net profit margin. For the net profit margin model, the firm-specific variable exports have shown a negative effect, whereas agriculture value added has shown a positive effect, ceteris paribus, and an increase in the export of agricultural raw materials does not increase the net profit margin of the agriculture firms in India.

The interest rate has shown a positive significant effect on net profit margin; a one-unit change in interest rate will result in a $30.99 \%$ increase in NPM. Inflation rate also shows a positive significant effect on NPM as a one-unit change in the inflation rate will result in a $21.77 \%$ increase in the net profit margin of agriculture firms. GDP has shown no significant effect on the net profit margin of the agriculture firms in India.

The coefficient of lagged ROA is positive and significant, which confirms that future financial performance depends on previous performance. The coefficient of agriculture exports (AEXP) is negative and significant at a $1 \%$ level, which is against the theory wherein a one-unit change in agriculture exports will result in a $1.15 \%$ decrease in ROA. The coefficient of AVAL is positive but not significant. The agricultural raw materials exports have shown a negative effect on the financial performance of the agriculture industry in India.

Interest rate and inflation have shown a negative significant effect on return on assets; a one-unit change in interest rate will result in a $0.53 \%$ decrease in $\mathrm{ROA}$, and a one-unit change in the inflation rate will result in a 0.10 $\%$ decrease in return on assets of agriculture firms. GDP has shown a significant positive effect on return on assets as a one-unit change in GDP will result in a $0.46 \%$ increase in return on assets.

The above models confirm that the dynamic panel regression is the best option. Past financial performance (NPM and ROA) is significantly related to future performance. The significant first order and the non-significant second order correlations also confirm the results. Further, the Sargan tests cannot reject the validity of the instruments and the Wald test confirms the joint significance of all variables in the model.

\section{CONCLUSION}

The financial performance of the agriculture industry in India is very poor as the financial measures of net profit margin and return on assets showed negative numbers during the period under study. The results show that exports of agricultural raw materials negatively affect the profitability of the firms, and therefore policymakers should focus on improving exports for profitability by diversifying the product portfolio and bringing in cost reduction measures. To improve financial performance, companies must adopt a price discovery mechanism for better commodity pricing and distribution facilities, which include retail, infrastructure and support from unnatural catastrophes. Improving asset management should be a priority for Indian agriculture firms because without it they can't generate enough income from their assets and beat competition in investment opportunities. 
The macroeconomic variables of inflation, interest rate and gross domestic product collectively influence the profitability of agriculture firms. The agriculture value addition to national income has shown a positive effect on the profitability of the agriculture firms in India. Based on the study results, it is concluded that an increase in agriculture value addition to GDP and diversified agriculture raw material exports would improve the return on assets of the agriculture firms and, in turn, improve the net profit margin.

Funding: This study received no specific financial support.

Competing Interests: The authors declare that they have no competing interests.

Authors' Contributions: All authors contributed equally to the conception and design of the study.

\section{REFERENCES}

Abbas, S. (2012). Causality between exports and economic growth: Investigating suitable trade policy for Pakistan. Eurasian Journal of Business and Economics, 5(10), 91-98.

Abolagba, E., Onyekwere, N., Agbonkpolor, B., \& Umar, H. (2010). Determinants of agricultural exports. Journal of Human Ecology, 29(3), 181-184.Available at: https://doi.org/10.1080/09709274.2010.11906261.

Ahmed, O., \& Sallam, W. (2018). Studying the volatility effect of agricultural exports on agriculture share of GDP: The case of Egypt. African Journal of Agricultural Research, 13(8), 345-352.Available at: https://doi.org/10.5897/ajar2016.1 1920.

Ali, S. (2017). Exchange rate effects on agricultural exports: Firm-level evidence from Pakistan. In University of Nottingham Discussion Paper No. (2017-09).

Anderson, T. W., \& Hsiao, C. (1981). Estimation of dynamic models with error components. Journal of the American statistical Association, 76(375), 598-606.Available at: https://doi.org/10.1080/01621459.1981.10477691.

Arellano, M., \& Bond, S. (1991). Some tests of specification for panel data: Monte Carlo evidence and an application to employment equations. The Review of Economic Studies, 58(2), 277-297.Available at: https://doi.org/10.2307/2297968.

Awan, A. G., \& Aslam, A. (2015). Impact of agriculture productivity on economic growth: A case study of Pakistan. In Global Journal of Management and Social Sciences, 1(1), 57-71.

Awokuse, T. O., \& Xie, R. (2015). Does agriculture really matter for economic growth in developing countries? Canadian Journal of Agricultural Economics, 63(1), 77-99.Available at: https://doi.org/10.1111/cjag.12038.

Ayinde, I. A., Ayanwale, A. O. S., Shittu, M. A., \& Kareem, R. O. (2013). Analysis of the performance of agro-based companies in the Nigerian stock exchange. Journal of Agribusiness in Developing and Emerging Economies, 3(2), 119-130.Available at: https://doi.org/10.1108/jadee-02-2013-0004.

Baharumshah, A. Z., \& Rashid, S. (1999). Exports, imports and economic growth in Malaysia: Empirical evidence based on multivariate time series. Asian Economic Journal, 13(4), 389-406.Available at: https://doi.org/10.1111/1467-8381.00092.

Bakari, S. (2017a). The impact of olive oil exports on economic growth: Empirical analysis from Tunisia. BILTÜRK Journal of Economics and Related Studies, 2(3), 441-458.

Bakari, S. (2017b). The impact of vegetables exports on economic growth in Tunisia. Economic Research Guardian, $7(2)$, $72-87$.

Bakari, S., \& Mabrouki, M. (2017). The effect of agricultural exports on economic growth in South-Eastern Europe: An empirical investigation using panel data. Journal of Smart Economic Growth, 2(4), 49-64.

Blundell, R., \& Bond, S. (1998). Initial conditions and moment restrictions in dynamic panel data models. Journal of Econometrics, 87(1), 115-143.Available at: https://doi.org/10.1016/s0304-4076(98)00009-8.

Boansi, D. (2013). Export performance and macro-linkages: A look at the competitiveness and determinants of cocoa exports, production and prices for Ghana, 1-32. Retrieved from: https://mpra.ub.uni-muenchen.de/48345/.

Bond, S. (2002). Dynamic panel data models: A guide to micro data methods and practice. Working Paper No. CWPo9/o2, Cemmap, Institute for Fiscal Studies.

Buguk, C., Isik, M., Dellal, İ., \& Allen, A. (2003). The Impact of exchange rate variability on agricultural exports of developing countries: The case of Turkey. Journal of International Food E Agribusiness Marketing, 13(1), 83-105.Available at: https://doi.org/10.1300/j047v13no1_06. 
Bulagi, M., Hlongwane, J., \& Belete, A. (2015). Causality relationship between agricultural exports and agricultures share of gross domestic product in South Africa: A case of avocado, apple, mango and orange from 1994 to 2011. African Journal of Agricultural Research, 1O(9), 990-994.Available at: https://doi.org/10.5897/ajar2014.8548.

Chi, J., \& Cheng, S. K. (2016). Do exchange rate volatility and income affect Australia’s maritime export flows to Asia? Transport Policy, 47, 13-21.Available at: https://doi.org/10.1016/j.tranpol.2015.12.003.

Donovan, W. G. (1996). Agriculture and economic reform in sub-Saharan Africa. 08213414. Retrieved from: https://agris.fao.org/agris-search/search.do? recordID=US2012401202.

Economic Survey. (202 1). Agriculture \& Food Management. (2021). 2, 230-233.

Edeme, R. K., Ifelunini, I. A., \& Nkalu, N. C. (2016). A comparative analysis of the impact of agricultural exports on economic growth of ECOWAS countries. In Acta Oeconomica Pragensia, 24(5), 31-46.Available at: https://doi.org/10.18267/j.aop.556.

Ekanayake, E. (1999). Exports and economic growth in Asian developing countries: Cointegration and error-correction models. Journal of Economic Development, 24(2), 43-56.

Emery, R. F. (1967). The relation of exports and economic growth. Kyklos, 20(4), 470-486.Available at: https://doi.org/10.1111/j.1467-6435.1967.tbo0859.x.

Faridi, M. Z. (2012). Contribution of agricultural exports to economic growth in Pakistan. Pakistan Journal of Commerce and Social Sciences, 6(1), 133-146.

Fosu, A. K. (1990). Exports and economic growth: The African case. World Development, 18(6), 831-835.Available at: https://doi.org/10.1016/0305-750x(90)90005-i.

Gilbert, N. A., Linyong, S. G., \& Divine, G. M. (2013). Impact of agricultural export on economic growth in Cameroon: Case of banana, coffee and cocoa. International Journal of Business and Management Reviere, 1(1), 44-71.

Gill, A., Mand, H., Obradovich, J., \& Mathur, N. (2018). The impact of financial support from non-resident family members on the financial performance of newer agribusiness firms in India. Journal of Agribusiness in Developing and Emerging Economies, 8(2), 303-319.

Gollin, D. (2010). Agricultural productivity and economic growth. Handbook of Agricultural Economics, 4, 3825-3866.Available at: https://doi.org/10.1016/S1574-0072(09)04073-0.

Hatemi-j, A. (2002). Export performance and economic growth nexus in Japan: A bootstrap approach. Japan and the World Economy, 14(1), 25-33.Available at: https://doi.org/10.1016/s0922-1425(01)00071-8.

Huchet, M., \& Korinek, J. (2011). To what extent do exchange rates and their volatility affect trade? , Doctoral Dissertation, AutoSaisine.

Hwa, E.-C. (1988). The contribution of agriculture to economic growth: Some empirical evidence. In World Development, $16(11)$, 1329-1339.Available at: https://doi.org/10.1016/0305-750x(88)90208-2.

Ijirshar, V. U. (2015). The empirical analysis of agricultural exports and economic growth in Nigeria. Journal of Development and Agricultural Economics, 7(3), 113-122.Available at: https://doi.org/10.5897/jdae2014.0615.

Issah, M., \& Antwi, S. (2017). Role of macroeconomic variables on firms' performance: Evidence from the UK. Cogent Economics \& Finance, 5(1), 1405581.Available at: https://doi.org/10.1080/23322039.2017.1405581.

Izuchukwu, O.-O. (2011). Analysis of the contribution of agricultural sector on the Nigerian economic development. World Revierw of Business Research, 1(1), 191-200.

Jatuporn, C., Chien, L.-H., Sukprasert, P., \& Thaipakdee, S. (2011). Does a long-run relationship exist between agriculture and economic growth in Thailand. International Journal of Economics and Finance, 3(3), 227-233.Available at: https://doi.org/10.5539/ijef.v3n3p227.

Kang, H. (2015). Agricultural exports and economic growth: Empirical evidence from the major rice exporting countries. Agricultural Economics, 61(2), 81-87.Available at: https://doi.org/10.17221/99/2014-agricecon. 
Katircioglu, S. T. (2006). Causality between agriculture and economic growth in a small nation under political isolation: A case from North Cyprus. International Journal of Social Economics, 33(4), 331-343.Available at: https://doi.org/10.1108/03068290610651643.

Khan, M. Z., \& Lodhi, A. S. (2014). Nexus between financial development, agriculture raw material exports, trade openness and economic growth of Pakistan. Pakistan Journal of Commerce and Social Sciences, 8(3), 629-639.

Khan, M. Z., Salam, A., \& Batool, A. (2015). Nexus between agricultural raw material exports, trade openness and economic growth of Pakistan. Journal of Agricultural Research, 53(4), 581-588.

Kiganda, E. O. (2014). Effect of macroeconomic factors on commercial banks profitability in Kenya: Case of equity bank limited. Journal of Economics and Sustainable development, 5(2), 46-56.

Kohler, A., \& Ferjani, A. (2018). Exchange rate effects: A case study of the export performance of the Swiss agriculture and food sector. The World Economy, 41(2), 494-518.Available at: https://doi.org/10.1111/twec.12611.

Mahmood, K., \& Munir, S. (2018). Agricultural exports and economic growth in Pakistan: An econometric reassessment. Quality E Quantity, 52(4), 1561-1574.Available at: https://doi.org/10.1007/s11135-017-0534-3.

Mao, R. (2019). Exchange rate effects on agricultural exports. China Agricultural Economic Review, 11(4), 600-62 1.Available at: https://doi.org/10.1108/caer-12-2017-0232.

Mehrara, M., \& Baghbanpour, J. (2016). The contribution of industry and agriculture exports to economic growth: The case of developing countries. World Scientific News, 46, 100-111.

Memon, M. H., Baig, W. S., \& Ali, M. (2008). Causal relationship between exports and agricultural GDP in Pakistan. Retrieved from: https://mpra.ub.uni-muenchen.de/11845/.

Mousavi, S., \& Leelavathi, D. (2013). Agricultural export and exchange rates in India: The Granger causality approach. International Journal of Scientific and Research Publications, 3(2), 1-8.

Murigu, J. W. (2014). The determinants of financial performance in general insurance companies in Kenya. University of Nairobi. Retrieved from: http://erepository.uonbi.ac.ke/handle/11295/74685.

Mwangi, F. K. (2013). The effect of macroeconomic variables on financial performance of aviation industry in Kenya. University of Nairobi. Retrieved from: http://erepository.uonbi.ac.ke/handle/11295/58551.

Njimanted, F. G., \& Aquilas, N. A. (2015). The impact of timber exports on economic growth in Cameroon: An econometric investigation. Asian Journal of Economic Modelling, 3(3), 46-60.Available at: https://doi.org/10.18488/journal.8/2015.3.3/8.3.46.60.

Ohlan, R. (2013). Agricultural exports and the growth of agriculture in India. Agricultural Economics, 59(5), 21 1-2 18.Available at: https://doi.org/10.17221/118/2012-agricecon.

Ojede, A. (2015). Exchange rate shocks and US services and agricultural exports: Which export sector is more affected? The International Trade Journal, 29(3), 228-250.Available at: https://doi.org/10.1080/08853908.2015.1024900.

Ojo, E. J., Awe, I. T., \& Ogunjobi, J. O. (2014). Agricultural export and economic growth in Nigeria: A multivariate Johansen cointegration analysis. International Journal of Arts and Commerce, 3(3), 89-98.

Olajide, O., Akinlabi, B., \& Tijani, A. (2012). Agriculture resource and economic growth in Nigeria. European Scientific Journal, $8(22), 103-115$.

Ongeri, G. M. (2014). The effect of macroeconomic variables on the financial performance of non-bank financial institutions in Kenya. University of Nairobi. Retrieved from: http://erepository.uonbi.ac.ke/handle/11295/77552.

Raza, S. A., Ali, Y., \& Mehboob, F. (2012). Role of agriculture in economic growth of Pakistan. International Research Journal of Finance and Economics, 83, 181-186.

Reaz, M., Bowyer, D., Vitale, C., Mahi, M., \& Dahir, A. M. (2020). The nexus of agricultural exports and performance in Malay sia: A dynamic panel data approach. Journal of Agribusiness in Developing and Emerging Economies, 10(5), 545-556.Available at: https://doi.org/10.1108/jadee-08-2019-0119. 
Reaz, M., Mahat, F., Dahir, A. M., Sahabuddin, M., Mahi, A., \& Masnun, A. S. M. (2017). Exchange rate volatility and financial performance of agriculture firms in Malaysia: An empirical analysis using GARCH, wavelet and system GMM. Business and Economic Horizons, 13(3), 409-427.Available at: https://doi.org/10.15208/beh.2017.29.

Ronit, M., \& Divya, P. (2014). The relationship between the growth of exports and growth of gross domestic product of India. International Journal of Business and Economics Research, 3(3), 135-139.Available at: https://doi.org/10.11648/j.ijber.20140303.13.

Sanjuán-López, A. I., \& Dawson, P. (2010). Agricultural exports and economic growth in developing countries: A panel cointegration approach. Journal of Agricultural Economics, 61(3), 565-583.Available at: https://doi.org/10.1111/j.14779552.2010.00257.x.

Shah, S. W. A., Haq, M., \& Farooq, R. (2015). Agricultural export and economic growth: A case study of Pakistan. Public Policy and Administration Research, 5(8), 88-96.

Sheefeni, J. P. S., \& Simon, R. (2016). Investigating the causal relationship between primary commodities exports and economic growth in Namibia.

Simasiku, C., \& Sheefeni, J. P. (2017). Agricultural exports and economic growth in Namibia. European Journal of Basic and Applied Sciences, 4(1), 41-50.

Singh, K., Misra, M., Kumar, M., \& Tiwari, V. (2019). A study on the determinants of financial performance of US agricultural cooperatives. Journal of Business Economics and Management, 20(4), 633-647.Available at: https://doi.org/10.3846/jbem.2019.9858.

Tang, C. F., Lai, Y. W., \& Ozturk, I. (2011). The stability of export-led growth hypothesis: Evidence from Asia's four little dragons, 1-13. Retrieved from: https://mpra.ub.uni-muenchen.de/52195/.

Tiffin, R., \& Irz, X. (2006). Is agriculture the engine of growth? Agricultural Economics, 35(1), 79-89.Available at: https://doi.org/10.1111/j.1574-0862.2006.00141.x.

Tulasombat, S., \& Ratanakomut, S. (2015). The effect of exchange rates on agricultural goods for export: A case of Thailand. Information Management and Business Review, 7(1), 1-11.Available at: https://doi.org/10.22610/imbr.v7i1.1133.

Urriola, C. N. N., Aquino Rodriguez, C. A., \& Baral, P. (2018). The impact of traditional and non-traditional agricultural exports on the economic growth of Peru: A short-and long-run analysis. Studies in Agricultural Economics, 120(3), 157165.Available at: https://doi.org/10.7896/j.1807.

Verter, N., \& Bečvářová, V. (2016). The impact of agricultural exports on economic growth in Nigeria. Acta Universitatis Agriculturae the Forestry Mendelianae Brunensis, 64(2), 691-700.Available at: https://doi.org/10.11118/actaun201664020691.

Wong, H.-T., \& Lee, H.-A. (2016). Exchange rate volatility and exports of Malaysian manufactured goods to China: An empirical analysis. International Journal of Business and Society, 17(1), 145 - 159.Available at: https://doi.org/10.33736/ijbs.518.2016.

Yao, S. (2000). How important is agriculture in China's economic growth? Oxford Development Studies, 28(1), 33-49.Available at: https://doi.org/10.1080/713688306.

Yusuf, S. (2014). Role of agriculture in economic growth \& development: Nigeria perspective. Germany: University Library of Munich. 